\title{
ŪMINIU GALVOS SMEGENŲ INFARKTU SERGANČIŲ IR INTRAVENINE TROMBOLIZE GYDYTŲ PACIENTŲ SAVARANKIŠKUMUI ITAKOS TURINTYS VEIKSNIAI
}

\author{
Henrikas Kazlauskas ${ }^{1}$, Elena Bovina ${ }^{2}$ \\ ${ }^{1}$ Klaipédos universitetiné ligonine, \\ ${ }^{2}$ Lietuvos sveikatos moksly universiteto Elgesio medicinos institutas
}

Raktažodžiai: ūminis galvos smegenų infarktas, intraveninè trombolizè, savarankiškumui įtakūs veiksniai.

\section{Santrauka}

Darbo tikslas buvo nustatyti ūminiu galvos smegenų infarktu sergančių ir intravenine trombolize gydytų pacientų savarankiškumui įtakos turinčius veiksnius. Retrogradiškai analizuoti 64 pacientų, gydytų Klaipėdos universitetinèje ligoninèje 2005$2014 \mathrm{~m}$. laikotarpiu, ligos istorijų duomenys. Insulto sunkumas ūmioje stadijoje vertintas pagal NIH insulto skalę (NIHSS), o savarankiškumas po trijų ménesių nuo ligos pradžios - pagal modifikuotą Rankin`o skalę. Duomenys buvo analizuojami statistinio paketo (SPSS) 17.0 versija. Tyrimas parodè, kad tarp pacientų grupių, kuriems intraveninè trombolizè atlikta iki $180 \mathrm{~min}$. ir per 181-270 min. laikotarpi nuo insulto pradžios, vertinant jų pradini neurologinị deficitą atvykimo ị stacionarą metu ir funkcinį priklausomumą po 3 mènesių, statistiškai patikimo skirtumo nenustatyta, atitinkamai $\mathrm{p}=0,283$ ir $\mathrm{p}=0,445$. Laikotarpis nuo hospitalizacijos iki intraveninès trombolizès pradžios (min.) tarp vyru ir moterų skyrèsi reikšmingai - vyrai 90,30 29,64 min., moterys $119,38 \pm 40,11 \mathrm{~min}$. ( $\mathrm{p}=0,006)$, o nuo susirgimo iki intraveninès trombolizès pradžios nereikšmingai $(\mathrm{p}=0,372)$. Lyginant funkcinio savarankiškumo skirtumus tarp lyčiu pagal modifikuotą Rankin`o skalę, nustatytas reikšmingai didesnis funkciškai savarankiškų vyrų skaičius, atitinkamai $23(88,5 \%)$ vyrai ir $6(46,2 \%)$ moterys $(\mathrm{p}=0,008)$. Be to, analizuojant tiriamuosius pagal skirtingas amžiaus grupes, $\leq 65 \mathrm{~m}$. ir $>65 \mathrm{~m}$., nustatytas reikšmingai didesnis trijų ménesių mirštamumas vyresniųų grupejje $(\mathrm{p}=0,012)$. Tyrimo analizè parodè, kad ligonių savarankiškumą reikšmingai veikè tik pradinis neurologinis deficitas (insulto sunkumas) susirgimo pradžioje, kuris funkciškai priklausomų grupejje nustatytas 14,8 $\pm 3,9$ balų, o savarankiškų 11,8 $\pm 4,1$ balų ( $\mathrm{p}=0,027)$. Remiantis tyrimo rezultatais padaryta išvada, kad pacientų, gydytų intravenine trombolize, savarankiškumas buvo reikšmingai sąlygojamas pradinio neurologinio deficito. Lyginant su moterimis, vyrų funkcinis savarankiškumas po 3 mėnesių nustatytas reikšmingai didesnis. Būtina sumažinti laikotarpị nuo pirmųų insulto simptomų iki gydymo intravenine trombolize taikymo pradžios.

\section{Ivadas}

Nuo 1996 m., kai JAV buvo įteisintas galvos smegenų infarkto gydymas intravenine trombolize, šis gydymo metodas dèl savo efektyvumo greitai paplito visame pasaulyje. Jau skaičiuojamas antras dešimtmetis, kai šis smegenų infarkto gydymas plačiai taikomas ir Lietuvoje. Tikètina, kad pacientų funkcinis savarankiškumas ištikus galvos smegenų infarktui po trijų mėnesių nuo insulto pradžios ir jam itakos turintys veiksniai yra ir ateityje bus svarbūs rodikliai vertinant ir prognozuojant šios ligos atokiuosius gydymo rezultatus. Atlikti tyrimai parode, kad keletas veiksnių yra susiję su geresniais gydymo rezultatais, esant ūminiam galvos smegenų infarktui taikant intraveninę trombolizę audinių plazminogeno aktyvatoriumi - tai jaunas amžius, lengvesnè insulto klinikinè forma, trumpesnis laikas nuo insulto iki intraveninès trombolizès pradžios, normalus gliukozės kiekis kraujuje bei gretutinių ligų nebuvimas [1]. Nors Lietuvoje ir atliktas panašaus pobūdžio tyrimas bei padaryta išvada, kad ankstyvas neurologinès būklès pagerèjimas leidžia numatyti palankią funkcinę išeitị [2], mūsų tyrimas papildo šiuos rezultatus, nes kai kurie asociaciniai ryšiai tarp veiksnių, turinčių įtakos pacientų savarankiškumui, po trijų mėnesių buvo analizuoti skirtingu aspektu.

Darbo tikslas - nustatyti intravenine trombolize gy- 
dytų pacientų savarankiškumui įtakos turinčius veiksnius.

\section{Kontingentas ir tyrimo metodai}

Retrogradiškai analizuoti 64 pacientų dèl ūminio galvos smegenų infarkto intravenine trombolize Klaipedos universitetinèje ligoninëje 2005-2014 m. laikotarpiu gydytų ligos istorijų (Forma Nr. 066/a-LK) duomenys. Pagal laiką nuo pirmujų insulto simptomų atsiradimo iki trombolizès pradžios visi tyrime dalyvaujantys buvę pacientai buvo suskirstyti i 2 grupes: i pirmają grupę ịtraukti ligoniai, kuriems trombolizè pradèta iki $180 \mathrm{~min}$. nuo insulto pradžios, i antrają pateko pacientai, kuriems nuo analizuojamos ligos iki intraveninès trombolizès pradžios praèjo 181-270 min. Pacientu insulto klinikinè sunkumo forma vertinta balais pagal NIHSS: vidutinè 5-15 balai, vidutiniškai sunki 16-20 balai, sunki forma 21-42 [3]. Tiriamujų savarankiškumas po trijų ménesių vertintas modifikuota Rankin'o skale [4], suskirsčius juos pagal funkcinę būklę ị dvi grupes: 0-2 balai - savarankiški ir 3-5 balai - nesavarankiški. Vertintas per pirmas 10 dienų ir 3 ménesius po intraveninès trombolizès mirusių pacientų skaičius. Duomenys buvo anali-

1 lentelè. Tiriamųjų charakteristikos

\begin{tabular}{|l|l|}
\hline \multicolumn{1}{|c|}{ Rodikliai } & \\
\hline Amžius (metais), vidurkis \pm SD & $65,8 \pm 12,4$ \\
\hline Vyrai, N (proc.) & $43(67,2 \%)$ \\
\hline Prieširdžių virpėjimas, N (proc.) & $15(23,4 \%)$ \\
\hline Cukrinis diabetas, N (proc.) & $1(1,6 \%)$ \\
\hline $\begin{array}{l}\text { Sistolinis arterinis kraujo spaudimas, vidurkis } \\
\pm \text { SD }\end{array}$ & $153,9 \pm 25,2$ \\
\hline $\begin{array}{l}\text { Diastolinis kraujo spaudimas, } \\
\text { vidurkis(mediana) }\end{array}$ & $89,79(90,0)$ \\
\hline $\begin{array}{l}\text { Laikas nuo susirgimo iki hospitalizacijos } \\
\text { (min.), vidurkis } \pm \text { SD }\end{array}$ & $70,6 \pm 43,0$ \\
\hline $\begin{array}{l}\text { Laikas nuo hospitalizacijos iki intraveninės } \\
\text { trombolizės pradžios (min.), vidurkis } \pm \text { SD }\end{array}$ & $99,8 \pm 35,9$ \\
\hline $\begin{array}{l}\text { Laikas nuo susirgimo iki intraveninės pradžios } \\
\text { (min.), vidurkis } \pm \text { SD }\end{array}$ & $170,4 \pm 42,2$ \\
\hline $\begin{array}{l}\text { NIHSS balai prieš intraveninę trombolizę, } \\
\text { vidurkis } \pm \text { SD }\end{array}$ & $13,0 \pm 4,2$ \\
\hline NIHSS balai po 2 val., vidurkis \pm SD & $10,4 \pm 6,0$ \\
\hline NIHSS balai po 24 val., vidurkis (mediana) & $10,0(8,0)$ \\
\hline NIHSS balai po 7 dienų, vidurkis (mediana) & $6,6(4,0)$ \\
\hline $\begin{array}{l}\text { Savarankiškumas (Rankin`o skalè po 3 mėn.), } \\
\text { N (proc.) }\end{array}$ & $19(29,74,4 \%)$ \\
$\begin{array}{l}\text { Savarankiški (0-2 balai) } \\
\text { Priklausomi (3-5 balai) }\end{array}$ \\
\hline $\begin{array}{l}\text { Per pirmas 10d. mirusių skaičius, N (proc.) } \\
\text { mirusių skaičius, N(proc.) }\end{array}$ \\
\hline
\end{tabular}

zuojami statistinio paketo (SPSS) 17.0 versija. Tikrintas intervalinių požymių pasiskirstymas pagal normalųjị dèsnị, taikant Shapir'o-Wilk'o testą. Požymių, turinčių normalųji pasiskirstymą, vidurkių palyginimui tarp dviejų nepriklausomų grupių naudotas neporinis Stjudent'o $(t)$ kriterijus (rezultatai lentelèse pateikti - vidurkis $\pm \mathrm{SD}$ (standartinis nuokrypis), o nesant normalaus pasiskirstymo - neparame-

2 lentelè. Analizuojamų veiksnių skirtumai tarp tiriamujų grupių priklausomai nuo insulto iki intraveninès trombolizès pradžios

\begin{tabular}{|c|c|c|c|c|}
\hline \multirow{3}{*}{ Rodikliai } & \multicolumn{4}{|c|}{$\begin{array}{l}\text { Laikas nuo simptomų atsiradimo } \\
\text { iki intraveninès trombolizès pradžios }\end{array}$} \\
\hline & $\begin{array}{l}\text { Iki } 180 \\
\text { min. }\end{array}$ & $\begin{array}{l}\text { 181-270 } \\
\text { min. }\end{array}$ & & \multirow[t]{2}{*}{$\mathbf{p}$} \\
\hline & $\mathrm{n}=44$ & $\mathbf{n}=\mathbf{2 0}$ & & \\
\hline Amžius (metais) & $65,6 \pm 12,4$ & $66,8 \pm 12,8$ & $\mathrm{t}=0,41$ & 0,688 \\
\hline Lytis: & & & $\chi^{2}=0,68$ & 0,409 \\
\hline Vyrai & $31(70,5 \%)$ & $12(60,0 \%)$ & & \\
\hline Moterys & $13(29,5 \%)$ & $8(40,0 \%)$ & & \\
\hline Prieširdžių virpèjimas & $11(25,0 \%)$ & $4(20,0 \%)$ & $\chi^{2}=0,19$ & 0,759 \\
\hline Cukrinis diabetas & - & $1(5,0 \%)$ & $\chi^{2}=2,24$ & 0,313 \\
\hline $\begin{array}{l}\text { Sistolinis arterinis } \\
\text { kraujo spaudimas }\end{array}$ & $150,3 \pm 24,2$ & $|162,6 \pm 24,5|$ & $\mathrm{t}=1,84$ & 0,075 \\
\hline $\begin{array}{l}\text { Diastolinis arterinis } \\
\text { kraujo spaudimas }\end{array}$ & $87,8(90,0)$ & $94,3(95,0)$ & $\mathrm{U}=297,0$ & 0,063 \\
\hline $\begin{array}{l}\text { Insulto sunkumo } \\
\text { klinikinè forma } \\
\text { (NIHSS balai } \\
\text { prieš intraveninę } \\
\text { trombolizę): }\end{array}$ & & & $\chi^{2}=2,52$ & 0,390 \\
\hline Vidutinè & $33(75,0 \%)$ & $13(65,0 \%)$ & & \\
\hline Vidutiniškai sunki & $11(25,0 \%)$ & $6(30,0 \%)$ & & \\
\hline Sunki & - & $1(5,0 \%)$ & & \\
\hline $\begin{array}{l}\text { Pradinis neurologinis } \\
\text { deficitas (NIHSS balai) }\end{array}$ & $12,6 \pm 4,1$ & $13,9 \pm 4,4$ & $\mathrm{t}=1,09$ & 0,283 \\
\hline $\begin{array}{l}\text { Neurologinis deficitas } \\
\text { (NIHSS balai) po } 2 \\
\text { val. }\end{array}$ & $10,1 \pm 6,4$ & $11,0 \pm 4,9$ & $\mathrm{t}=0,59$ & 0,557 \\
\hline $\begin{array}{l}\text { Neurologinis deficitas } \\
\text { (NIHSS balai) po } 24 \\
\text { val. }\end{array}$ & $10,0(9,0)$ & $10,0(7,0)$ & $\mathrm{U}=339,5$ & 0,877 \\
\hline $\begin{array}{l}\text { Neurologinis deficitas } \\
\text { (NIHSS balai) po } 7 \\
\text { dienų }\end{array}$ & $7,3(4,0)$ & $4,7(2,0)$ & $\mathrm{U}=222,0$ & 0,509 \\
\hline Mirè & $13(29,5 \%)$ & $6(30,0 \%)$ & $\chi^{2}=0,01$ & 0,971 \\
\hline $\begin{array}{l}\text { Mirties laikotarpis } \\
\text { (paros) }\end{array}$ & $19,69(4,0)$ & $6,5(7,0)$ & $\mathrm{U}=39,0$ & 0,999 \\
\hline \begin{tabular}{|c|} 
Savarankiškumas po 3 \\
mèn. (Rankin'o skalè): \\
Savarankiški \\
Priklausomi \\
\end{tabular} & $\begin{array}{c}18(69,2 \%) \\
8(30,8 \%)\end{array}$ & $\left|\begin{array}{c}11(84,6 \%) \\
2(15,4 \%)\end{array}\right|$ & $\chi^{2}=1,08$ & 0,445 \\
\hline
\end{tabular}


trinis Mann'o-Whitney (U) kriterijus (rezultatai lentelèse pateikti - vidurkis (mediana). Kokybinių požymių priklausomumo ir homogeniškumo vertinimui naudotas chi kvadrato $\left(\chi^{2}\right)$ kriterijus, o esant mažoms imtims - patikslintas Fisher'o testas. Analizuojant koreliacinius požymių ryšius,

3 lentelè. Amžiaus, arterinio kraujo spaudimo, ivvairių laikotarpių iki intraveninès trombolizès pradžios ir NIHSS rodiklių skirtumai priklausomai nuo tiriamujų savarankiškumo

\begin{tabular}{|c|c|c|c|c|}
\hline \multirow{3}{*}{ Rodikliai } & \multicolumn{4}{|c|}{ Rankin'o skalè } \\
\hline & $\begin{array}{l}\text { Priklausomi } \\
\text { (3-5 balai) }\end{array}$ & $\begin{array}{l}\text { Savarankiški } \\
(0-2 \text { balai })\end{array}$ & & $\mathbf{p}$ \\
\hline & $\mathrm{n}=\mathbf{1 0}$ & $\mathrm{n}=\mathbf{2 9}$ & & \\
\hline Amžius & $69,3 \pm 11,6$ & $60,7 \pm 12,9$ & $\mathrm{t}=1,87$ & 0,082 \\
\hline Sistolinis arterinis kraujo spaudimas & $155,5 \pm 16,7$ & $155,8 \pm 24,0$ & $\mathrm{t}=-0,04$ & 0,933 \\
\hline Diastolinis arterinis kraujo spaudimas & $91,4(90,0)$ & $91,1(90,0)$ & $\mathrm{U}=133,0$ & 0,811 \\
\hline $\begin{array}{l}\text { Laikotarpis nuo susirgimo iki } \\
\text { hospitalizacijos (min.) }\end{array}$ & $64,8 \pm 44,1$ & $76,1 \pm 42,1$ & $\mathrm{t}=-0,72$ & 0,664 \\
\hline $\begin{array}{l}\text { Laikotarpis nuo hospitalizacijos iki } \\
\text { intraveninės trombolizès pradžios } \\
\text { (min.) }\end{array}$ & $105,3 \pm 39,0$ & $96,0 \pm 38,2$ & $\mathrm{t}=0,66$ & 0,699 \\
\hline $\begin{array}{l}\text { Laikotarpis nuo susirgimo iki } \\
\text { intraveninès trombolizės pradžios } \\
\text { (min.) }\end{array}$ & $170,1 \pm 33,5$ & $172,0 \pm 50,6$ & $\mathrm{t}=-0,14$ & 0,897 \\
\hline $\begin{array}{l}\text { Pradinis neurologinis deficitas } \\
\text { (NIHSS balai) }\end{array}$ & $14,8 \pm 3,9$ & $11,8 \pm 4,1$ & $\mathrm{t} 2,04$ & 0,027 \\
\hline $\begin{array}{l}\text { Neurologinis deficitas (NIHSS balai) } \\
\text { po } 2 \text { val. }\end{array}$ & $15,2 \pm 3,5$ & $7,7 \pm 4,9$ & $\mathrm{t}=4,43$ & $<0,001$ \\
\hline $\begin{array}{l}\text { Neurologinis deficitas (NIHSS balai) } \\
\text { po } 24 \text { val. }\end{array}$ & $16,2(17,0)$ & $4,8(4,0)$ & $\mathrm{U}=16,0$ & $<0,001$ \\
\hline $\begin{array}{l}\text { Neurologinis deficitas (NIHSS balai) } \\
\text { po } 7 \text { dienų }\end{array}$ & $15,5(17,0)$ & $2,6(1,0)$ & $\mathrm{U}=10,0$ & $<0,001$ \\
\hline
\end{tabular}

4 lentelè. Analizuojamų požymių skirtumai pagal lytị

\begin{tabular}{|l|c|c|c|c|}
\hline \multicolumn{1}{|c|}{ Rodikliai } & Vyrai & Moterys & & p \\
\hline Amžius & $63,98(66,0)$ & $69,52(70,0)$ & $\mathrm{U}=329,0$ & 0,080 \\
\hline $\begin{array}{l}\text { Laikotarpis nuo susirgimo iki } \\
\text { hospitalizacijos (min.) }\end{array}$ & $77,05 \pm 41,74$ & $57,33 \pm 43,47$ & $\mathrm{t}=1,726$ & 0,092 \\
\hline $\begin{array}{l}\text { Laikotarpis nuo hospitalizacijos iki } \\
\text { intraveninés trombolizes pradžios } \\
\text { (min.) }\end{array}$ & $90,30 \pm 29,64$ & $119,38 \pm 40,11$ & $\mathrm{t}=-2,952$ & 0,006 \\
\hline $\begin{array}{l}\text { Laikotarpis nuo susirgimo iki } \\
\text { intraveninės trombolizes pradžios } \\
\text { (min.) }\end{array}$ & $167,35 \pm 45,01$ & $176,71 \pm 35,78$ & $\mathrm{t}=-0,901$ & 0,372 \\
\hline Sistolinis arterinis kraujo spaudimas & $155,12 \pm 26,88$ & $151,43 \pm 21,75$ & $\mathrm{t}=0,586$ & 0,561 \\
\hline Diastolinis arterinis kraujo spaudimas & $90,43(90,0)$ & $88,52(90,0)$ & $\mathrm{U}=397,0$ & 0,511 \\
\hline $\begin{array}{l}\text { Pradinis neurologinis deficitas } \\
\text { (NIHSS balai) }\end{array}$ & $12,26 \pm 4,14$ & $14,48 \pm 3,97$ & $\mathrm{t}=-2,071$ & 0,045 \\
\hline $\begin{array}{l}\text { Neurologinis deficitas (NIHSS balai) } \\
\text { po 2 val. }\end{array}$ & $9,53 \pm 5,89$ & $12,19 \pm 5,85$ & $\mathrm{t}=-1,70$ & 0,096 \\
\hline $\begin{array}{l}\text { Neurologinis deficitas (NIHSS balai) } \\
\text { po 24 val. }\end{array}$ & $9,23(7,0)$ & $11,61(11,5)$ & $\mathrm{U}=294,5$ & 0,269 \\
\hline $\begin{array}{l}\text { Neurologinis deficitas (NIHSS balai) } \\
\text { po 7 dienu }\end{array}$ & $5,74(3,0)$ & $8,31(9,5)$ & $\mathrm{U}=233,0$ & 0,409 \\
\hline Mirties laikas (paros) & $15,33(5,0)$ & $15,86(4,0)$ & $\mathrm{U}=32,5$ & 0,418 \\
\hline
\end{tabular}

\section{Rezultatai ir ju aptarimas}

Pirmoje lenteleje pateiktų tiriamujų charakteristikose matyti, kad pacientu amžiaus vidurkis buvo $65,8 \pm 12,4$ metų. Nustatyta, kad laiko nuo insulto pradžios iki hospitalizacijos vidurkis buvo $70,6 \pm 43,0$ minučiu, nuo hospitalizacijos iki intraveninès trombolizès pradžios - 99,8 335,9 min., o laiko nuo insulto iki intraveninès trombolizès pradžios $170,4 \pm 42,2$ min. Tyrimas parode, kad pacientų neurologinès būklès sunkumas, vertinto pagal NIHSS, prieš pradedant trombolizę vidurkis $13,0 \pm 4,2$ balų. Lyginant mūsų pacientų ir Vilniuje atlikto tyrimo duomenis matyti, kad tirtų pacientų amžius buvo panašus $(66,3 \pm 15,0 \mathrm{~m}$. ir $65,8 \pm 12,4 \mathrm{~m}$.), atitinkamai Vilniuje ir Klaipèdoje, tačiau pacientų vidutinis neurologinis deficitas atvykimo i stacionarą metu $(15,0 \pm 5,4$ balų Vilniuje ir $13 \pm 4,2$ balų Klaipèdoje) Vilniaus mieste buvo didesnis [2]. Be to, analizès metu paaiškejjo, kad laikas nuo insulto pradinių simptomų iki gydymo intravenine trombolize pradžios (146,9 $\pm 43,9$ min.) 23,5 min. buvo ilgesnis Klaipeddos universitetinejje ligoninejje. Per pirmas 10 dienų po intraveninès trombolizés dèl įvairiu komplikaciju mire 14 ( 21,8 proc.), o per pirmus 3 mènesius - 19 (29,6 proc.) visu pacientų. Pacientų, gydytų intravenine trombolize, mūsų ligoninèje mirštamumas bei jo galimos priežastys buvo analizuotos ankstesniame mūsų tyrime [5].

Antroje lentelèje pateikti tyrimo rezultatai parode, kad pirmoje analizuojamoje grupeje intrave- 
nine trombolize gydytų pacientu skaičius buvo daugiau negu dvigubai didesnis $(\mathrm{n}=44)$, lyginant su antraja grupe $(\mathrm{n}=20)$. Tai galima aiškinti ta priežastimi, kad pacientus gydyti intravenine trombolize praejus $270 \mathrm{~min}$. nuo insulto pradžios Lietuvoje pradèta tik keletą pastarujų metų ir todèl jų skaičius tyrime pateiktas mažesnis. Moksliniuose tyrimuose nustatyta, kad pacientų, atvykusių trijų valandų laikotarpiu, gydymo intravenine trombolize efektyvumas - reikšmingai didesnis, lyginant su atvykstančiais vèlesniu laiku $[6,7]$. Mūsų tyrime nenustatyta reikšmingų skirtumų tarp tiriamuju grupių priklausomai nuo insulto iki intraveninès trombolizès pradžios (iki 180min. ir 181-270 min.) laiko. Viena iš priežasčių, ypač vertinant savarankiškumą po trijų mẻnesių, galèjo būti mažas pacientų skaičius antroje analizuojamoje grupeje. Kita galima svarbi priežastis buvo ta, kad pradinis neurologinis deficitas, kuris yra svarbus geresniu gydymo rezultatu prognostinis veiksnys [8], tarp grupių statistiškai reikšmingai nesiskyre $(12,6 \pm 4,1$ ir $13,9 \pm 4,4 ; \mathrm{p}=0,283)$. Be to, pacientų amžius, nuo kurio taip pat priklauso gydymo intravenine trombolize rezultatai [9], nors ir nustatytas kiek didesnis antroje grupejje, reikšmingai nesiskyrè.

Kaip matyti iš trečioje lentelèje pateiktų duomenų, nustatyti reikšmingi $(\mathrm{p}<0,05)$ NIHSS rodiklių, vertintų skirtingais laiko intervalais, skirtumai priklausomai nuo savarankiškumo (Rankin`o skalè). Mokslinių tyrimų rezultatai rodo, kad gliukozès kiekis, arterinis kraujo spaudimas, laikas nuo insulto pradžios bei pradinis neurologinis deficitas sąlygoja intraveninio trombolizės gydymo rezultatus [6,912]. Iš trečioje lentelèje pateikiamų rezultatų matyti, kad tiriamiesiems, kurie po trijų mėnesių tapo nepriklausomi,

5 lentelė. Tiriamųjų insulto klinikinès formos sunkumo, pagal NIHSS balus, ir 3 mėnesių savarankiškumo, pagal Rankin`o skalę, vertinimų skirtumai tarp vyrų ir moterų grupių

\begin{tabular}{|c|c|c|c|c|}
\hline Rodikliai & Vyrai & Moterys & $\chi^{2}$ & $\mathbf{p}$ \\
\hline $\begin{array}{l}\text { NIHSS balai } \\
\text { prieš intraveninę }\end{array}$ & & & 3,019 & 0,215 \\
\hline $\begin{array}{l}\text { Vidutinè } \\
\text { insulto forma }\end{array}$ & $33(76,7 \%)$ & $13(61,9 \%)$ & & \\
\hline $\begin{array}{l}\text { Vidutiniškai } \\
\text { sunki insulto } \\
\text { forma }\end{array}$ & $10(23,3 \%)$ & $7(33,3 \%)$ & & \\
\hline $\begin{array}{l}\text { Sunki insulto } \\
\text { forma }\end{array}$ & - & $1(4,8 \%)$ & & \\
\hline $\begin{array}{l}\text { Savarankiškumas } \\
\text { (Rankin'o skalè } \\
\text { po } 3 \text { mèn.) }\end{array}$ & & & 8,136 & 0,008 \\
\hline Savarankiški & $23(88,5 \%)$ & $6(46,2 \%)$ & & \\
\hline Priklausomi & $3(11,5 \%)$ & $7(53,8 \%)$ & & \\
\hline
\end{tabular}

per visus laiko intervalus, prieš ir po gydymo intravenine trombolize, buvo nustatytas statistiškai patikimai mažesnis neurologinis deficitas. Lyginant su kitų autorių tyrimų rezultatais paaiškejja, kad mūsų gydytų pacientų bendras vidutinis pradinis neurologinis deficitas $(13,0 \pm 4,2$ balų) buvo didesnis, nei kituose tarptautiniuose tyrimuose: SITS-ISTR registro duomenimis, vidutinis neurologinis deficitas buvo 11-12 balo pagal NIHSS [13], ECASS 3 tyrime vidutinis neurologinis deficitas buvo 10,7 NIHSS balo [14]. Paminèti veiksniai galėjo sąlygoti ir mūsų tiriamujų gydymo rezultatus, vertinant Rankin o skale. Kitų analizuotu veiksnių skirtumai funkciniam savarankiškumui po trijų mėnesių statistiškai buvo nereikšmingi.

Epidemiologinių tyrimų sisteminès apžvalgos rezultatai parodè, kad moterys ūminiu insultu serga sunkiau [15]. Mūsų tyrimas tai patvirtino, nes vertinant tiriamujų analizuotų požymių sąsajas tarp skirtingų lyčių (4 lentelè), nustatyta, kad balų skaičius pagal NIHSS skalę prieš intraveninę trombolizę (vyrai 12,26 $\pm 4,14$ balų, moterys $14,48 \pm 3,97$ balų: $p=0,045$ ) buvo reikšmingai didesni moterų grupejje.

Be to, laikas nuo hospitalizacijos pradžios iki intraveninès trombolizès pradžios (vyrai 90,30 $\pm 29,64$ min., moterys $119,38 \pm 40,11$ min., $p=0,006$ ) buvo statistiškai patikimai didesnis taip pat moterų grupeje. Šio laiko skirtumo priežastis lieka neaiški. Kitų analizuojamų požymių skirtumai tarp lyčių nustatyti statistiškai nereikšmingi (4 lentelè).

Nors vertinant pradini neurologinį deficitą nustatytas statistiškai reikšmingas skirtumas tarp lyčių, $(p=0,045)$ (4 lentelè), tačiau analizuojant pagal 2 ir 24 val. bei $7 \mathrm{~d}$. periodus reikšmingų skirtumų nenustatyta (5 lentelè). Šis skirtumas statistiškai patikimai $(\mathrm{p}=0,008)$ išryškèja anali-

6 lentelė. NIHSS balų vertinimų pagal laiko intervalus sąsajos su Rankin'o skale po 3 mėnesių skirtingose tiriamujų amžiaus grupèse

\begin{tabular}{|l|c|c|c|c|}
\hline \multirow{2}{*}{ Rodikliai } & \multicolumn{4}{|c|}{ Rankin'o skalė } \\
\cline { 2 - 5 } & \multicolumn{2}{|c|}{$\begin{array}{c}\text { Iki 65 metų } \\
\text { (imtinai) }\end{array}$} & \multicolumn{2}{c|}{$\begin{array}{c}\text { Vyresni nei 65 } \\
\text { metu }\end{array}$} \\
\cline { 2 - 5 } & $\mathbf{r}$ & $\mathbf{p}$ & $\mathbf{r}$ & $\mathbf{p}$ \\
\hline $\begin{array}{l}\text { NIHSS balai prieš } \\
\text { intraveninę trombolizę }\end{array}$ & 0,63 & 0,004 & 0,29 & 0,211 \\
\hline $\begin{array}{l}\text { NIHSS balai po 2 val. } \\
\text { atlikus intraveninę } \\
\text { trombolizę }\end{array}$ & 0,74 & $<0,001$ & 0,65 & 0,002 \\
\hline $\begin{array}{l}\text { NIHSS balai po 24 } \\
\text { val. atlikus intraveninę } \\
\text { trombolizę }\end{array}$ & 0,87 & $<0,001$ & 0,73 & $<0,001$ \\
\hline $\begin{array}{l}\text { NIHSS balai po 7 dienų } \\
\text { atlikus intraveninę } \\
\text { trombolizę }\end{array}$ & 0,95 & $<0,001$ & 0,86 & $<0,001$ \\
\hline
\end{tabular}


zuojant savarankiškumą po trijų mėnesių pagal Rankin `o skalę - funkciškai savarankiškų vyrų 23 (88,5 proc. ) buvo žymiai daugiau nei moterų 6 (46,2 proc.). Blogesnius rezultatus moterų grupeje galèjo nulemti vyresnis amžius (4 lentelè) bei galimai gausesnis lydinčių ligų skaičius šioje grupeje $[16,17]$.

Šeštoje lenteleje pateikti duomenys rodo, kad NIHSS vertinimas balais (insulto klinikinès formos sunkumas) beveik visuose laiko intervaluose (išskyrus prieš intraveninę trombolizę vyresniųų grupeje) abiejose amžiaus grupèse statistiškai reikšmingai susijęs su savarankiškumo vertinimu pagal Rankin`o skalę. Nors mūsų tyrime reikšmingo skirtumo tarp amžiaus grupių neišryškèjo, bet autoriai, tyrę amžiaus ịtaką gydymo intravenine trombolize rezultatams, nustate, kad vyresniesiems pacientų gydymo rezultatai blogesni, nes jie serga sunkesnemis insulto formomis, jų savarankiškumas iki insulto būna mažesnis, o komplikacijų skaičius didesnis [9]. Be to, šioje amžiaus grupejje būna daugiau moteru, jos serga sunkesnèmis insulto klinikinèmis formomis, o jų funkcinès būklès ir mirštamumo rodikliai blogesni $[12,18]$.

\section{Išvados}

1. Pacientų dèl galvos smegenų infarkto gydytų intravenine trombolize savarankiškumą po trijų mènesių labiausiai veikè pradinis neurologinis deficitas.

2. Lyginant su moterimis, vyrų funkcinis savarankiškumas po 3 mènesių nustatytas reikšmingai didesnis.

3. Būtina sumažinti laikotarpi nuo pirmųų insulto simptomų iki gydymo intravenine trombolize taikymo pradžios.

\section{Literatūra}

1. Saposnik G, Reeves MJ, Johnston SG. et al. Predicting Clinical Outcomes After Thrombolysis Using the iScore. Results From the Virtual International Stroke Trials Archive. Stroke 2013; 44: $2755-2759$.

http://dx.doi.org/10.1161/STROKEAHA.113.001343

2. Vilonskis A., Knoknerienė O., Šešeikatė M. ir kt. Ankstyvo neurologinio pagerèjimo po intraveninès trombolizės, gydant ūminịi išeminįi insultą, klinikinè reikšmè ir prognostiniai veiksniai. Neurologijos seminarai, 2013; 17(57): 217-222.

3. National Institutes of Health Stroke Scale. Prieiga per internetą. http://en.wikipedia.org/wiki/National_Institutes_of_Health_Stroke_Scale

4. Modified Rankin's scale. Prieiga per internetą. http://www. strokecenter.org/wp-content/uploads/2011/08/modified_rankin. pdf

5. Kazlauskas H., Bukauskas G., Janušonis V. ir kt. Sergančiuju ùminiu galvos smegenų išeminiu insultu gydymo intravenine trombolize rezultatai Klaipėdos universitetinèje ligoninèje
2005-2010 metais. Sveikatos mokslai, 2011; 21(4): 74-79.

6. Lees KR, Bluhmki E, von Kummer R. et al. Time to treatment with intravenous alteplase and outcome in stroke: an updated pooled analysis of ECASS, ATLANTIS, NINDS, and EPITHET trials. Lancet 2010; 375(9727): 1695-1703. http://dx.doi.org/10.1016/S0140-6736(10)60491-6

7. Wardlaw JM, Murray V, Berge E. et al. Thrombolysis for acute ischemic stroke. Cochrane Database Syst Rev 2014;7: CD000213. doi.1002/14651858.CD000213.pub3.

8. Franke MR, Morgenstern LB, Kwiatkowski T. et al. Predicting prognosis after stroke: a placebo group analysis from National Institute of Neurological Disorders and Stroke rt-PA stroke trial. Neurology 2000; 55: 952-959.

http://dx.doi.org/10.1212/WNL.55.7.952

9. Miller DJ, Simpson JR, Silver B. Safety of Thrombolysis in Acute Ischemic Stroke: A Review of Complications, Risk Factors, and Newer Technologies. The Neurohospitalist 2011; 1(3): 138-147.

http://dx.doi.org/10.1177/1941875211408731

10. Ahmed N, Davalos A, Erikson N. et al. Association of admission blood glucose and outcome in patients treated with intravenous thrombolysis: results from the Safe Implementation of Treatments in Stroke International Stroke Thrombolysis Register (SITS-ISTR). Arch Neurol 2010; 67(9): 1123-1130. http://dx.doi.org/10.1001/archneurol.2010.210

11. Dharmasaroja PA, Muengtaweepongsa S, Dharmasaroja P. Early outcome after intravenous thrombolysis in patients with acute ischemic stroke. Neurol India 2011; 59(3): 351-354.

http://dx.doi.org/10.4103/0028-3886.82723

12. Emberson J, Lees KR, Lyden P. et al. Effect of treatment delay, age, and stroke severity on the effects of intravenous thrombolysis with alteplase for acute ischaemic stroke: a meta-analysis of individual patient date from randomised trials. Lancet 2014; 384(9958): 1929-1935.

http://dx.doi.org/10.1016/S0140-6736(14)60584-5

13. Wahlgren N, Ahmed N, Davalos A. et al. Thrombolysis with alteplase 3-4.5 $\mathrm{h}$ after acute ischaemic stroke (SITS-ISTR): an observational study. Lancet 2008; 372: 1303-1309.

http://dx.doi.org/10.1016/S0140-6736(08)61339-2

14. Hacke W, Kaste M, Bluhmki E. et al. Thrombolysis with alteplase 3 to 4.5 hours after acute ischemic stroke. NEJM. 2008; 359: 1317-1329.

http://dx.doi.org/10.1056/NEJMoa0804656

15. Haast RA, Gustafson DR, Kiliaan AJ. Sex differences in stroke. J Cereb Blood Flow Metab 2012 Dec; 32(12): 2100-2107. http://dx.doi.org/10.1038/jcbfm.2012.141

16. Reeves MJ, Bushnell CD, Howard G. et al. Sex differences in stroke: epidemiology, clinical presentation, medical care, and outcomes. Lancet Neurol 2008 October; 7(10): 915-926. http://dx.doi.org/10.1016/S1474-4422(08)70193-5

17. Apperlos P, Stegmayr B, Tere'nt A. Sex Differences in Stroke 
Epidemiology. A systematic review. Stroke 2009; 40: 1082 1090.

http://dx.doi.org/10.1161/STROKEAHA.108.540781

18. Hsu LC, Fuh JL. Benefit or harm: Does age matter in stroke outcome after thrombolysis? J Chin Med Assoc 2014; 77: $167-168$.

http://dx.doi.org/10.1016/j.jcma.2014.02.003

\section{FACTORS INFLUENCING AUTONOMY OF PATIENTS WITH ACUTE BRAIN INFARCTION WHO UNDERWENT INTRAVENOUS THROMBOLYSIS}

\section{H. Kazlauskas, E. Bovina}

Key words: acute brain infarction, intravenous thrombolysis, factors influencing autonomy.

Summary

The aim of the study was to identify factors that influenced autonomy of patients with acute brain infarction to whom intravenous thrombolysis had been applied. Retrograde analysis was used to investigate medical history data of 64 patients treated in Klaipeda University Hospital during the period of 2005-2014. Severity of stroke in the acute phase was evaluated using the NIH Stroke Scale (NIHSS) and patients' autonomy three months after the onset of the disease was assessed according to the modified Rankin scale. The data was analysed using version 17.0 of the Statistical Package for the Social Sciences (SPSS). The study found no statistically significant difference in groups of patients to whom intravenous thrombolysis had been performed up to $180 \mathrm{~min}$ and between $181 \mathrm{~min}$ and $270 \mathrm{~min}$, when assessing their initial neurological deficit at the time of entering the hospital and functional dependence after three months, respectively, $\mathrm{p}=0.283$ and $p=0.445$. The period between hospitalisation and the beginning of intravenous thrombolysis ( $\mathrm{min}$ ) differed significantly among men and women: men $90.30 \pm 29.64$, women $119.38 \pm 40.11$ ( $\mathrm{p}=0.006$ ); whereas the difference of the time interval between the incidence and the start of thrombolysis was insignificant $(\mathrm{p}=0.372)$. When comparing gender differences in autonomy according to the modified Rankin scale, significantly higher number of functionally autonomous men was observed: $23(88.5 \%)$ men and 6(46.2\%) women $(\mathrm{p}=0.008)$. In addition, when analysing different age groups, $\leq 65$ years and $>65$ years, significantly higher three-month mortality in senior patients was identified $(\mathrm{p}=0.012)$. The analysis showed that patients' autonomy was significantly influenced only by initial neurological deficit (stroke severity) at the beginning of the disease, constituting $14.8 \pm 3.9$ points within functionally dependent group and $11.8 \pm 4.1$ points in the autonomous group $(\mathrm{p}=0.027)$. Based on the results, the study concluded that autonomy of patients who had been treated with intravenous thrombolysis was significantly influenced by the initial neurological deficit. In comparison to women, significantly higher functional autonomy of men after three months was observed. It is necessary to reduce the period between the first symptoms of stroke and the start of intravenous thrombolytic treatment.

Correspondence to: h.kazlauskas@takas.lt

Gauta 2015-05-17 